\title{
Education Concept by KH Morality, Munir Ahmad and Implementation in Modern Cottage Muhammadiyah Paciran Lamongan
}

\author{
Himmatul Husniyah,
}

Biyanto

\author{
Master of Islamic Education Management, \\ Universitas Muhammadiyah Sidoarjo, Indonesia \\ himma_cahchyrant@yahoo.co.id, \\ mrbiyanto@gmail.com
}

\begin{abstract}
Insight Education must be free from bondage and narrow, primordial, and exclusive barriers of thought. Education should be based on morality. This research is conducted at The Modern Cottage Paciran Muhammadiyah Lamongan with the problem formulation: (1) How is the concept of moral education According to KH. Ahmad Munir? (2) How is the implementation of moral education According to KH. Munir Ahmad at Muhammadiyah Paciran Modern Cottage ?. In the data collection the author uses observation documentation and interview methods. While the data to the analysis uses descriptive analysis of data from interviews with eight informants. From the results of the study can be Obtained the description that, the thoughts of KH. Munir Ahmad rejected the dichotomy of science. Islamic education is education that leads to the liberation of students and democratic, it means that it Gives freedom to ask questions, be critical and debatable. The curriculum form has the dimensions of integrated curriculum mattered, with the basic principle that is capable of giving birth to a building of an ummatic curriculum. The significance of the moral education curriculum and the learning methodology in Pondok Modem Muhammadiyah Paciran is quite significant, its implementation is based on interviews from 8 informants items, namely two students and six religious teachers and religious teachers.
\end{abstract}

Keywords: Moral Education, KH. Munir Ahmad.

\section{INTRODUCTION}

Education issues are not separated by humans, it is as old as human life itself. Education starts from Adam received a lesson on the names of objects in the world, as revealed by Allah in the Qur'an, "And He taught Adam the names (objects) entirely, then bring it to the Angels and then said:" Tell me the names of these things if you do spot the right people the right "[1].

In that event has occurred which was later renamed the education process. Education is a conscious effort to prepare learners to have a role in the future. The future can we predictive of phenomenon now is a period that will be marked problem complexity of interconnected and has taken a role in moving the process of universal civilization, namely through the development of engineering and industry, the global economic system and the free market, communication networks and advanced information, the development of weapons systems that increasingly has a tremendous destructive power, knowledge about the increasingly destructive destruction of natural resources for the preservation of humanity and the environment, the population explosion in many countries, Thus there is no choice but to accept the presence of life's multi-ethnic, multi-cultural, multi ideology and multi religious in this global society.

By looking at education from a global complexity of the issue, both in terms of the risks faced and the opportunities that are open, it becomes clear adult education and science is faced with a new task which is large and heavy. Science education, educators and educational elements must have a universal point of view and it is a principle of international perspective that should apply to nations, countries and cultures. Insights education should be free from the shackles and barriers of narrow thinking, primordial, and exclusive and must have a good moral [2].

How the role, mission and anticipation of Islamic education in Indonesia? Will go with the flow without performing selective borrowing related to fundamental and philosophical foundation? Can Islamic education exist and competitively in the global network? What is also variable and the theory of education should be developed? 
To answer the questions above, will be compounded when faced with the challenge of Islamic education in today's world in the global arena, as happened ambivalent there. On the one hand, an Islamic education is required to maintain and transmit the values, morals and ethics of Islam to students. On the other hand, Islamic education increasingly demanded actuality and discourse power in the globalized world antisipatifnya. In practice, the poor students menghormti teachers, lack of respect for elders around him. Therefore, moral education is indispensable. The views KH. Munir Ahmad in a globalized world to defend the values of religion firmly as a person who holds the coals. As a result of suffering alienation of modern man, both from himself, the social environment as well as his Lord.

In the midst of that birth is also an alternative thinkers, KH. Ahmad Munir was born in 1942, KH. Ahmad Munir is the caretaker of Pondok Modern Muhammadiyah Lamongan Paciran progressive [3] in managing education. KH educational concept. Munir Ahmad apply to students-santrinya is a morality-based education.

\section{Types of Research}

\section{MAIN PART}

In this study the author uses descriptive analytical method, ie research that revealed the circumstances, occurrences and events ongoing in nature (natural setting) at a location to be studied, namely in Pondok Modern Paciran Muhammadiyah Lamongan.

\section{2.}

Place and time of research

This study will be conducted in Pondok Modern Paciran Muhammadiyah Lamongan., Which is located on Jl. The cottage, alley KH .. Ridwan Syarqowi RT 04 RW 05, Village Paciran Paciran District of Lamongan, East Java. The research conducted at the time of Pondok Modern Paciran Muhammadiyah Lamongan is for 3 months, starting in December 2017 until February 2018.

\section{Types and Sources of Data}

A study certainly needed their types and sources of data so that the research can be accounted for. As in this study using the types and sources of data as follows:

\section{a.Primary data}

The primary data source is a data source that provided data to the data collector directly (object of study) [4]. The primary data source is the main source is needed in this research, in order to obtain accurate data. As for the source of primary data in this study there were several informants. Informants who have totaled 8 of them are KH. Ahmad Munir, KH. Ahmad Ahzab, Drs. Muhammad Hasan Rasidi, M.Pd.I, Djauhara Maknunah, S.Pd, Fachruddin AM, Rifqi Rosyidi, Lc. M.Ag, Richah Dian and Muhammad Aunur Rifqi. With reference to the guidelines for the interview.

\section{b. Secondary Data}

Secondary data sources are sources that do not directly provide data to data collectors, for example through others or through documents. This data source is a data source in the research or data supporting both tangible documentation data and field data available.

In this study, which is the source of secondary data is Pondok Modern profile Paciran Muhammadiyah Lamongan and other data required as supporting data research. advertising, ktematonim is primarily represented by verbal and non-verbal elements. When choosing ktematonim, the meaning of the word should be short and clear, the product's essence, and the need to have a sense of its impact on the consumer's mind depends on the advertising agency that attracts advertisers and the customers. The selection of ktematonim based on the product's essence plays an important role in selling, however, the richness and efficiency of the advertising product. The combination of form and content plays an important role in the selection of grammatical structures that reflect the lexemes.

\section{Data collection technique}

In this study the authors collected data using several methods as follows:

\section{a. Observation Methods}

An observation method is a technique that is done by conducting observations accurately and systematically recording. [5] This method I use to obtain information about the state of the research object, the state of infrastructure, and the state of the facilities to support teaching and learning in modern cottage Paciran Muhammadiyah Lamongan. 


\section{b. Interview Method}

Interview or interview method is a method used to get answers from the respondents to the question and answer unilaterally.

This method is used to obtain information from any data source on education morality applied in modern cottage Paciran Muhammadiyah Lamongan.

\section{c. Methods Documentation}

Documentation methods that find data on things or variables in the form of notes, transcripts, books, newspapers, magazines, inscriptions, minutes of meetings, legger, agendas, and so on.

This method is done by citing a record of the history of the lodge, the identity of the lodge, the vision and mission of the cottage, the organizational structure of the cottage, the purpose of the cottage, the data chaplain and students, the state of infrastructure, or certain records to provide evidence or information about a event.

\section{DATA ANALYSES AND RESULTS}

As an effort to transform the attitude of morality, then it can be viewed as sentrumnya education. What is the attitude and behavior of students after school or outside school, aqidah morality lesson will be very influential. Like the saying, then the child will be good or bad depending curriculum materials aqidah morality. Therefore, it would be possible if the model of learning is learning model as had been applied during the New Order regime, then there is the next generation of a mentally stunted, short-sighted, and the direction, not the generation of matureminded, independent, and respect for diversity. Education transformative education become very expensive, because it actually happened is merely the process of knowledge transfer miskm reality. Bending his back in front of the religious scholars / teachers,

Munir Kyai criticism against morality education lies in teaching methods that are less democratic, and distortions of the meaning of morality is essential. From either the correction of some imbalances present educational process Kyai tried to put forward Munir ideally concepts of Islamic education. The process of education in the perspective of Islam (the learning process), should be able to explore the potential of learners as optimal and as early as possible, both physically and spiritually, according to the tempo of its development. Such efforts balls continuous, simultaneous, and to take benefit of the forces of human and non-human, beyond the students, with no escape from divine ethics frame which he believed.

In order to realize the above, the strategy most appropriate educational system developed is the education system morality.Namely the education system oriented to the development potential of learners in a democratic, by giving them the freedom to choose and develop their potential, according to its inclination and berakhlaqul karimah. That is, an education system that implemented a process of further aid from adults in directing the development of potential learners to always conform and stay on the desired path (path goodness).

Understanding education as a morality which says Kyai Munir is education that leads to liberation and democratic learners; intention to give freedom to the students to ask questions, be critical and debatable (debate teacher / kyainya), the ethics of mutual respect and respect the differences of opinion that was born humanization of education (humanizing protege and justice).

The importance of the concept of morality adaptik ummatik education in order to improve the quality of human resources. Due to media education is a tool that is most powerful and effective in mewamai civilization and the human personality, as the final goal of education are implemented. In this context, there are three alternative approaches to the concept of moral education system:First,take the western educational system has to offer, as a force of civilization of the world today. This approach has the disadvantage, due to different cultures, cultural values, and purpose of civilizations between the West and Islam. Second, take Islamic education system through the excavation of the values or signals that exist in the Qur'an and Hadith, directly or indirectly, without notice and taking into account especially. Adopting the evolving education system today; the dominance of western education system offered that consciously or not, have entered the entire human kehidaupan atmosphere modem. Third, assimilation accommodating between western education systems offered with the values contained in the teachings of Islam (al-Quran and al-Hadith).

The third group, which was developed under the concept of moral education with the hope will be able to produce a form of dialogical education system, inclusive, effective and efficient based on the values of Islamic philosophical.

The concept of moral education is, more focused on:

a. Dialogical learning methodology, debatable and not doctrinaire dogmatikal polyinterpretable.

b. Shape which has dimensions of integrated curriculum vitae mattered (integrate the material with the spiritual), with the basic principle that is able to produce a curriculum ummatik building. 
c. Educator as a facilitator or directional, while the students as friends as companions to the Messenger of Allah considers his students.

To arrive at the above objectives, education akhlaqgive rights to people (students and teachers), to be free and independent in using or developing the existing variety of subject matter, as long as all of them capable of reaching a Islàm educational purposes. In this dimension, the learning process will be flexible and universal. This is because the process is continuous education offered. This dimension is put educationakhlaqbased on the concept of the deity and social nature monistic evaluation, then an integrated philosophy addressed to plenary terwuiudnya Muslim personality and for the good of all mankind. He was given the freedom to use a variety of media lessons for the highest achievement of his life as the final point of his existence on earth.

The shape of the curriculum offered by the moral education has dimensions integrated curriculum mattered.Its existence is only a basic reference (as raw material) which is used as a foothold in the learning process more focused. not as a final reference standard. Adaptik is dynamic in nature, in accordance with the acceleration of human culture that is dynamic and complex. Contained a reference material to be able to touch all the interests, dimensions, vision, and potential learners are intact and are universal. This discourse signaled that the curriculum offered by the education morality, looked at the charge contains material that must be constantly network interconnected with one another in their entirety and interdependence. In this context it is visible, that in Islamic education does not recognize partial dualism in curriculum content, as presented this adult contemporary education $[5]$.

To build a dynamic curriculum that is proportional, then the perspective of moral education,keep in mind some basic principles of curriculum. By paying attention to these basic principles, is expected to be able to bring a buildingummatik curriculum. Basic principles, among others: the philosophical principle, the principle of psychological integralistic, sociological principles, scope let curriculum materials in harmony with human nature, shape the curriculum offered operasionalistik be realistic and can be implemented in accordance with the capabilities and situations of learners and are effective and efficient for life.

Seeing so broad and universality of coverage offered education curriculum morality,presumably form appropriate curricula to protect all cargo in Islamic education, is to use an integrated form or corelated curriculum vitae. Because with terpolanya form such curriculum, it would help learners develop all their potential optimally. On the other hand, learners can discover the nature of his wine development and humanitarian potential to develop the most appropriate for the functions and duties caliphate on earth that would account for vertically or horizontally [6].

From the description above can be the common thread that moral education curriculum has dimensions mattered integrated curriculum with reference to the material contained in touch all the interests, dimensions, vision, and potential learners are intact and are universal. And its significance to the curriculum applied in Pondok Modern Muhammadiyah Paciran include the values mentioned above, as disclosed by Kyai Munir. Whereas, cottage curriculum are: the Qur'an, al-Hadith, Tafsir, Fiqh, Aqeedah and Akhlaq, Bhs.Arab (nahwu and sorof), rhetoric. Average common curriculum can be obtained at Madrasi educational pathways (formal). So the cottage curriculum and school curriculum support each other and support each other.

From interviews with the author-cleric religious teachers and students about the curriculum in modern lodge the results strongly support the curriculum applied in modern cottage Lamongan Muhammadiyah Paciran this. Among the interviews conducted by the author with one cleric Drs. M. Hasan Rasidi, M.Pd.I. which states that the existing curriculum in modern cottage is nice because students can get would ideally need knowledge and deepening of religion [7].

Djauhara Maknunah, S.Pd one ustdzah in modern cottage Paciran Lamongan Muhammadiyah, said that the curriculum is applied in this modern cottage is a very good curriculum for students-students need to gain insightful material that religion [8].

M. 'Aunur Rifqi one of the students in a modern cottage Paciran Muhammadiyah Lamongan said that it supports the curriculum applied in modern cottage Paciran muhammadiyah this, because the materials obtained are very capable of adding knowledge-knowledge about religion and can be used in the course of their education provision later [9].

Thus we can conclude that the moral education curriculum and its implementation in Pondok Modem Muhammadiyah Paciran significant proven students and chaplain / cleric expressed support to the curriculum cottage Paciran Modem Muhammadiyah Lamongan.

From gambarun above, Munir Kyai thinking about the morality of no significance learning method with learning methods applied in Pondok Modem Muhammadiyah Paciran, and to prove its implementation in Pondok Modem Muhammadiyah Paciran (outside lane madrasa education / formal).

From interviews with the author-cleric religious teachers and students about learning methods applied in modern cottage result strongly agree. Among the interviews conducted by the author with one cleric is Fachruddin AM stating that it could not agree with the methods applied in Pondok Modern Muhammadiyah Lamongan Paciran this because with these methods students can get the materials to maximize religion [10]. 
Rifqi Rosyidi, Lc. M.Ag one cleric in modern cottage Paciran Lamongan Muhammadiyah is also said that it agrees with the method applied in this modern cottage because with this method the morality of learning in the learning activities closer to the students, so that the material submitted by Ustadz-cleric can well received by the students [11].

Richah Dian one of the students in a modern cottage Paciran Muhammadiyah Lamongan said that it agreed with the teaching methods applied in modern cottage Paciran muhammadiyah this, because the methods applied are learning how to be more fun [12].

Thus the implementation of moral education learning method in Pondok Modern Paciran Muhammadiyah significant, it is evident that the students and the preachers agree on system applied learning by Muhammadiyah Paciran Modem cottage. As revealed by KH. Ahmad Munir, that this modern lodge combines two methods: traditional and modern.

\section{CONCLUTION}

\section{Education concept Akhlaq According to KH. Munir Ahmad}

Demand KH. Ahmad Munir that, let Islamic education able to foster critical and creative power, intelligence root of personal, social and humanitarian. Education is very rigid morality must be revamped and standardized methodology. Education morality are identical to the bending his back in front of the teacher / clerics, soar not grounded, God is seen as the proprietary rights not owned by someone else, worship hanva pertaining to God, not human-related, educational models doctrinaire-dogmatikal let already started revamped with a model dialogical nature of education, debatable and polyinterpretable that leads to a democratic education, the educational dimension of morality.

Education morality in question is education that leads to the release of the students and democratic; give freedom to ask questions, be critical and debatable, in the ethics of mutual respect and respect the differences of opinion, so was born the humanization of education (humanizing protege and justice).

Average educational concept morality in question, more focused on:

a.Dialogical learning methodology, debatable and not doctrinaire dogmatikal polyinterpretable.

b.Shape which has dimensions of integrated curriculum vitae mattered (integrate the material with the spiritual), with the basic principle that is able to produce a curriculum ummatik building.

c.Educator as a facilitator or directional, while the students as friends as companions of the Prophet considers his students.

\section{II.Implementation of moral education according to KH. A. Munir in Pondok Modern Paciran Muhammadiyah Lamongan}

Modern cottage Muhammadiyah Paciran curriculum include values as expressed by KH. A. Munir that curriculum cottage is: al-Qur'an, al-Hadith, Tafsir, Fiqh, Aqeedah morality, Bhs. Arab (nahwu and sorof), rhetoric. Average general lesson can be obtained dijalur madrasa education (formal). So the cottage curriculum and school curriculum menupang each other and support each other. Implementation, based on the results of interviews and the ustadh students about their curriculum Paciran Pondok Modern Muhammadiyah is strongly supported by a number of reasons that have been given. And thus it can be concluded that the moral education curriculum and its implementation in Pondok Modern Muhammadiyah Paciransignificant proved most students sons / daughters and expressed support to the curriculum ustàdh Pondok Modern Muhammadiyah Paciran.

Meanwhile, based on the responses of students and the ustàdh about their teaching methods Pondok Modern Muhammadiyah Paciran be known very much agree with the arguments that have been spoken. It is thus the implementation of moral education learning method in Pondok Modern Muhammadiyah Paciransignificant, $\mathrm{O}$ is evident that most students sons / daughters and ustàdh agree on applied learning system by Muhammadiyah Paciran Modern cottage.

\section{REFERENCES}

1. "The Qur'an."

2. M. Ahmad, Modern cottage Paciran Mudir Muhammadiyah Lamongan, results of the interviews. Lamongan.

3. A. Ahzab, Modern cottage Mudir I Paciran Muhammadiyah Lamongan, results of the interviews. Lamongan.

4. Sugiyono, Qualitative and Quantitative Research Methods R \& D. Bandung: Alfabeta.

5. H. Langgulung, Humanand Education - A Ana lisa Psychology and Education. Jakarta: Pustaka al-Husna.

6. Nasution, Principles of Curriculum. Jakarta: Literacy Development.

7. M. H. Rasidi, Modern cottage Paciran Ustadz Muhammadiyah Lamongan, results of the interviews. Lamongan.

8. D. Maknunah, Modern cottage Paciran Ustadzah Muhammadiyah Lamongan, results of the interviews. Lamongan.

9. M. A. Rifqi, Paciran students of Pondok Modern Muhammadiyah Lamongan, results of the interviews. 


\section{Lamongan.}

10. F. AM, Modern cottage Paciran Ustadz Muhammadiyah Lamongan, results of the interviews. Lamongan.

11. R. Rosyidi, Modern cottage Paciran Ustadz Muhammadiyah Lamongan, results of the interviews. Lamongan.

12. [12] R. Dian, Paciran students of Pondok Modern Muhammadiyah Lamongan, results of the interviews. Lamongan. 